JEL: G33, Q14

\author{
Liudmyla Dorohan-Pysarenko ${ }^{1}$, Rafat Rębilas ${ }^{2}$, Olena Yehorova ${ }^{1}$, \\ Ilona Yasnolob ${ }^{I}$, Zhanna Kononenko ${ }^{I}$ \\ ${ }^{1}$ Poltava State Agrarian University \\ ${ }^{2}$ WSB University in Dąbrowa Górnicza \\ ${ }^{1}$ Ukraine \\ ${ }^{2}$ Poland
}

\title{
METHODOLOGICAL PECULIARITIES OF PROBABILITY ESTIMATION OF BANKRUPTCY OF AGRARIAN ENTERPRISES IN UKRAINE
}

Purpose. The purpose of the study is to develop the concept of complex estimation of bankruptcy probability of agrarian enterprises in Ukraine, taking into account the specifics of agricultural activities.

Methodology / approach. To achieve the purpose, the following research methods were used: abstract-logical (at disclosing the essence of the concept of "bankruptcy"); dialectical (for theoretical generalizations on determining the problems and ways to overcome them, drawing conclusions); expert estimations, comparative analysis, analysis and synthesis (at developing the concept of estimating the probability of bankruptcy); relative indicators-coefficients (at studying models for estimating the probability of bankruptcy occurrence); monographic (for in-depth study of separate types of factors affecting the probability of bankruptcy); graphical and tabular (at presenting the research results).

Results. It has been proven that the discriminant analysis for estimating the probability of bankruptcy (the construction of multifactor models that summarize the most important financial indicators in the integrated index) does not take into account the industry characteristics of agrarian enterprises. The concept of bankruptcy diagnostics is proposed, which combines discriminant analysis and expert estimation of qualitative signs of a possible crisis of an agrarian enterprise. The indicators selected for expert examination cover non-financial factors - the risks and threats to agricultural production in Ukraine, and their generalization may specify the risk of bankruptcy occurrence. The scoring model has been derived by the method of expert estimations, the scale has been developed, which is combined with the discriminant one that will enable to bring the results of the research into the interval of the indicator for estimating the occurrence of bankruptcy.

Originality / scientific novelty. The definition of the term "bankruptcy" has been improved: the author's definition combines the economic and legal approaches to it. The main risks of agricultural activities in Ukraine have been specified and their impact on the probability of bankruptcy of agrarian enterprises has been outlined. It has been developed the methodological concept for estimating the probability of bankruptcy of agrarian enterprises, which takes into account informal factors. For the first time, in order to predict the bankruptcy of agrarian enterprises, it has been proposed to combine discriminant analysis and expert estimation of qualitative indicators that increase its risk in agriculture.

Practical value / implications. The application of the developed methodology provides an opportunity for the agrarian enterprise of timely responding to the threats of financial crisis and bankruptcy in order to prevent them. The proposed approach can be used as an element of estimating the insurance risk or investment attractiveness of agricultural enterprises. In case of its adaptation, the methodology can be used in foreign practice.

Key words: agriculture, bankruptcy, methods of estimating the probability of bankruptcy. 


\section{Agricultural and Resource Economics: International Scientific E-Journal}

http://are-journal.com

Introduction and review of literature. Bankruptcy is an inseparable mechanism of market economy, a tool for freeing the market from inefficient enterprises. In market conditions, any entity can go bankrupt, differing only in the degree of risk of bankruptcy occurrence. That is why monitoring the signs of insolvency and possible financial crisis, estimating the probability of bankruptcy occurrence are necessary for a rapid response to the threats.

Because of the absence of relevant information in open sources, it is possible to estimate the dynamics of agrarian enterprises' bankruptcies in Ukraine only indirectly. For example, the number of economic entities "Agriculture, forestry and fishing industry" over the past decade decreased by $6.1 \%$ - from 80,321 in 2010 to 75,450 in 2019 [1]. But, given the well-grounded fears that after the opening of the agricultural land market in Ukraine on July 1, 2021, small farmers will find it difficult to compete with agro-holdings and the number of bankruptcies of agrarian enterprises may increase.

In practice however, classical approaches of discriminant analysis are widely used to estimate the probability of bankruptcy and the methodological provisions approved by the Government bodies are also used, the generally accepted "record of diagnosis" of bankruptcy is currently absent.

In our opinion, the problem consists not only in the fact that bankruptcy estimation is the estimation of risks that are difficult to measure, but also its methodology cannot be universal. Bankruptcy prediction must be based not only on the calculation of financial coefficients, but also take into account the conditions and specifics of business activities' sectors. Thus, the study of methodology for estimating the probability of bankruptcy of agrarian enterprises in Ukraine remains topical.

Although, the entrepreneurs have long been interested in the issue of assessing the probability of bankruptcy, effective attempts to create the methods for estimating it were recorded only in the second half of the XX century.

Theoretical, methodological and practical aspects of bankruptcy risk were considered in the works of such prominent scientists as E. I. Altman [2], J. Argenti [3], W. Beaver [4], F. H. Knight [5], T. Scone [6], G. L. V. Springate [7], J. N. Tetens [8], and others. Modern foreign scientists, in particular, D. Alaminos, A. del Castillo, M. Á. Fernández [9], A. Jaki, W. Cwiek [10], J. Horváthová, M. Mokrišová [11], B. Prusak [12], T. Shumway [13], N. Bărbuță-Mișu, M. Madaleno [14] have achieved significant results in improving the models of diagnosing and estimating bankruptcy of companies. At present, many studies are being conducted to predict the bankruptcy of neural networks, researching neural network methods of T. Hosaka [15], A. Papana, A. Spyridou [16] and others.

Among the recent publications, J. B. Heaton's paper [17] attracts attention: the author provides data concerning errors in estimating the probability of bankruptcy according to Altman's model in 98-98 \% of cases and proves that modern bankruptcy prediction models must be based not on accounting ratios but on market data. O. Lukason and A. Andresson, whose approach is new, prove that the information on the company's debt for tax gives a higher accuracy of forecasts than its financial ratios, so it is expedient to combine these indicators in a combined regression model [18]. 


\section{Agricultural and Resource Economics: International Scientific E-Journal}

http://are-journal.com

At the same time, many scholars pay attention to the need of taking into account industry risks when analyzing the probability of bankruptcy. For example, A. Lilia and J.-P. Huiban [19], after examining the activities of food industry companies in France proved that the structure of bankruptcy risk in this area differs from the risks of other manufacturing enterprises.

The peculiarities of estimating bankruptcy probability of agrarian enterprises are studied by R. Dinterman, A. L. Katchova, M. J. Harris [20], K. Valaskova, P. Durana, P. Adamko, J. Jaros [21], G. V. Savytska [22].

Ukrainian scientists have also developed methodological recommendations for estimating the probability of enterprise's bankruptcy aimed at diagnosing its financial and economic state by structural indicators of production activity. The methods of estimating the probability of bankruptcy are currently being studied, in particular, by O. O. Tereshchenko [23], T. O. Melikhova [24], V. I. Rudyka, and Yu. M. Velykyi [25]. Sector aspects of analyzing the probability of bankruptcy have been covered in the works of such Ukrainian agricultural scientists as A. V.Chupis [26] and O. M. Tranchenko [27].

The methodology of estimating the probability of bankruptcy proposed by A.V. Chupis [26] is the first one developed by the Ukrainian economist for agrarian enterprises. However, its disadvantage is including of only two indicators of financial state in the discriminant model and ignoring the indicators of profitability. That is why the use of this method does not provide high accuracy in estimating the probability of bankruptcy.

The discriminant model of bankruptcy prediction developed by O. O. Tereshchenko [23], in particular its variant, which includes ten financial indicators, has gained wide recognition. The coefficient values of universal independent variables of these indicators in the regression equation are differentiated depending on the type of enterprises' economic activities. That is, improving the quality of estimating the probability of bankruptcy of an agrarian enterprise according to this model is provided by the industry differentiation of financial indicators' impact on the possibility of the study object default. According to the author, the error in estimating the probability of bankruptcy for agrarian enterprises does not exceed $7.8 \%$.

O. M. Tranchenko also used discriminant analysis to predict the bankruptcy of agrarian enterprises [27]. Fewer number of regression equation variables (six) is the peculiarity of his model. It is also characterized by including here not only financial indices, but also return on investment - the index characterizing the use of basic means of activity. However, the model has an economically illogical connection - the increase in return on investment increases the probability of bankruptcy. The scholar explains this in the following way: as in the agrarian enterprises of Cherkasy region during the study period, their own agricultural machinery was mostly worn out, it was actively rented, which led to a decrease in operating costs and increased the risk of bankruptcy. According to the author' data, the accuracy of predicting the bankruptcy of an agrarian enterprise according to this model makes $89.3 \%$ in the year of forecasting and $76.8 \%$ during the two-year period. However, taking into account the above-mentioned 


\section{Agricultural and Resource Economics: International Scientific E-Journal}

http://are-journal.com

methodological feature, the prediction for other objects will likely be less accurate.

The considered above and other available models are based mainly on the calculation of financial ratios and do not take into account the impact of industry risks and business conditions in a particular country, so the methods of estimating the probability of bankruptcy need further improvement, considering the specifics of the agrarian sector.

The purpose of the article. The purpose of the study is to develop the concept of complex estimation of bankruptcy probability of agrarian enterprises in Ukraine, taking into account the specifics of agricultural activities.

To achieve this goal, the following tasks were set:

- to summarize the main factors that increase the probability of bankruptcy for agrarian enterprises in Ukraine;

- to consider the most widespread methods of estimating the probability of bankruptcy of agrarian enterprises;

- to propose the concept of the authors' methodology of estimating the probability of bankruptcy of agrarian enterprises.

Methodological approaches to estimating the probability of bankruptcy of agrarian enterprises are the object of study.

Results and discussions. Estimating the probability of bankruptcy involves, first of all, a clear definition of this term. At present, the available definitions of "bankruptcy" characterize this process mainly from the legal or economic point of view.

Definitions of bankruptcy in the Ukrainian legislation are given in the Code of Ukraine in Bankruptcy Proceedings, the Commercial Code and indirectly in the Criminal Code. The key phrases in the legal definitions of this term are "the court pronounced inability of the debtor to restore his (her) solvency" and "financial insolvency". However, it is incorrect to identify bankruptcy with insolvency in general, as there are several levels of insolvency, in particular, the current one, which most companies experience from time to time.

Definitions of the term "bankruptcy", which represent the most widespread approaches to the definition according to the financial aspect, specify that in case of bankruptcy the lack of payment means to cover liabilities is critical or supercritical, i.e. the sum of debt significantly exceeds high- and medium-operating assets. However, in determining the essence of bankruptcy by economists, the attention is not paid to the fact that this state can only be evidenced in the court. We propose the definition that combines both the economic and legal aspects of bankruptcy recognition: "Bankruptcy is a court-recognized state of supercritical entity's insolvency, characterized by the insufficiency of its operating assets to pay liabilities".

The agrarian sector is one of the riskiest sectors of the economy, in which it is difficult to estimate the probability of failure. The reason of it is the presence of threats and risks inherent both in any area of business activities and certain industry.

In our opinion, the methodology of estimating bankruptcy probability of an agrarian enterprise must take into account the degree of entrepreneurial risk in the industry. Theoretical and methodological aspects of business risks in the agrarian 


\section{Agricultural and Resource Economics: International Scientific E-Journal http://are-journal.com}

sector have been studied by us in previous papers [28].

The essence of separate threats and their possible impact on the loss of solvency, and as a consequence on bankruptcy probability of an agrarian enterprise, have been worked out in detail in Table 1.

Table 1

\section{The main threats to agricultural activities and their impact on increasing the probability of an agrarian enterprise bankruptcy}

\begin{tabular}{|c|c|c|}
\hline $\begin{array}{c}\text { Peculiarity of agricultural } \\
\text { production }\end{array}$ & $\begin{array}{c}\text { Possible threats associated with the } \\
\text { peculiarity of the activity }\end{array}$ & $\begin{array}{l}\text { The impact of the threat on } \\
\text { the probability of bankruptcy }\end{array}$ \\
\hline $\begin{array}{l}\text { 1. Impossibility of complete } \\
\text { control over the production } \\
\text { process and its result due to } \\
\text { dependence on weather and } \\
\text { climatic conditions, } \\
\text { biological processes }\end{array}$ & $\begin{array}{l}\text { Complete or partial loss of finished } \\
\text { products, biological assets of crop } \\
\text { growing and livestock farming, } \\
\text { production stocks, etc. as a result of } \\
\text { emergencies, adverse weather } \\
\text { conditions, animal and plant diseases }\end{array}$ & $\begin{array}{l}\text { Receiving less than due } \\
\text { incomes from selling } \\
\text { products. Decrease in assets, } \\
\text { in particular, high- and } \\
\text { medium-operating. Bearing } \\
\text { losses as a result of losing } \\
\text { resources and products } \\
\end{array}$ \\
\hline $\begin{array}{l}\text { 2. Interaction with the } \\
\text { environment, the state of } \\
\text { the environment }\end{array}$ & $\begin{array}{l}\text { Risk of reducing soil fertility. } \\
\text { Decreasing the amount of manufactured } \\
\text { products, reducing their quality, banning } \\
\text { the selling of low-quality products. The } \\
\text { possibility of environmental pollution, } \\
\text { the results of which are fines, the loss of } \\
\text { reputation, deterioration of relations with } \\
\text { local authorities and the community }\end{array}$ & $\begin{array}{l}\text { Losses as a result of } \\
\text { reduced revenues from } \\
\text { selling products and } \\
\text { paying fines for } \\
\text { environmental pollution }\end{array}$ \\
\hline $\begin{array}{l}\text { 3. Seasonal prevalence of } \\
\text { technological processes }\end{array}$ & $\begin{array}{c}\text { The uneven use of resources during the } \\
\text { year, fluctuations in the need for } \\
\text { working capital }\end{array}$ & $\begin{array}{c}\text { The necessity for additional } \\
\text { financing of current needs } \\
\text { in certain periods }\end{array}$ \\
\hline $\begin{array}{l}\text { 4. Long duration of } \\
\text { production cycle for some } \\
\text { industries (livestock } \\
\text { farming, horticulture, } \\
\text { viticulture, etc.) }\end{array}$ & $\begin{array}{l}\text { Impossibility to react quickly to changes } \\
\text { in market conditions (for example, it } \\
\text { takes more than three years to grow a } \\
\text { dairy herd, more than five years - to } \\
\text { create a new orchard, and more than } \\
\text { three years - a vineyard, etc.) }\end{array}$ & $\begin{array}{l}\text { Significant investment lag } \\
\text { between investment and } \\
\text { payback. In the conditions } \\
\text { of inflation, it devalues the } \\
\text { income. The need for loan } \\
\text { financing of current needs }\end{array}$ \\
\hline $\begin{array}{l}\text { 5. The need for following } \\
\text { technological continuity }\end{array}$ & $\begin{array}{l}\text { The lack of irreplaceable resources } \\
\text { (feed, fuel, seeds during the sowing } \\
\text { period, etc.) can lead to complete or } \\
\text { partial loss of products }\end{array}$ & $\begin{array}{l}\text { The necessity to direct a } \\
\text { significant part of working } \\
\text { capital to the formation of } \\
\text { production stocks }\end{array}$ \\
\hline $\begin{array}{l}6 . \text { The use of part of own } \\
\text { products in manufacturing }\end{array}$ & $\begin{array}{l}\text { Part of the manufactured products } \\
\text { remains to satisfy the internal needs } \\
\text { (seeds, young animals, feed, etc.). Self- } \\
\text { reproduction of a part of resources } \\
\text { reduces the level of production } \\
\text { marketability }\end{array}$ & $\begin{array}{l}\text { The reduction of income } \\
\text { from selling products. } \\
\text { Insufficient volume of } \\
\text { manufacturing own } \\
\text { products leads to costs for } \\
\text { their buying }\end{array}$ \\
\hline $\begin{array}{l}\text { 7. Significant area of } \\
\text { production, remoteness } \\
\text { from places of selling }\end{array}$ & $\begin{array}{l}\text { Large transport costs. Product losses } \\
\text { during transportation }\end{array}$ & $\begin{array}{l}\text { Increased logistics costs. } \\
\text { Possible losses of income } \\
\text { because of poor quality } \\
\text { and/or products' loss } \\
\text { during transportation. }\end{array}$ \\
\hline
\end{tabular}




\begin{tabular}{|c|c|c|}
\hline \multicolumn{3}{|r|}{ Continuation of table 1} \\
\hline $\begin{array}{l}\text { 8. Orientation of many } \\
\text { enterprises to export } \\
\text { products }\end{array}$ & $\begin{array}{l}\text { Changing the state of international } \\
\text { markets. The existence of export quotas } \\
\text { for certain goods. The dependence of } \\
\text { income on the national currency } \\
\text { exchange rate }\end{array}$ & Loss of part of income \\
\hline 9. The use of leased land & $\begin{array}{c}\text { The possibility of termination or non- } \\
\text { renewal of the lease agreement by } \\
\text { landowners }\end{array}$ & $\begin{array}{l}\text { Possible reducing the } \\
\text { manufacturing of products } \\
\text { as a result of reducing the } \\
\text { sown areas. Revenue } \\
\text { reduction }\end{array}$ \\
\hline $\begin{array}{l}\text { 10. The lack of highly } \\
\text { qualified personnel in the } \\
\text { industry }\end{array}$ & $\begin{array}{c}\text { The low level of labor productivity, } \\
\text { product shortages }\end{array}$ & $\begin{array}{c}\text { Loss of assets and } \\
\text { revenues }\end{array}$ \\
\hline $\begin{array}{l}\text { 11. Instability of land and } \\
\text { tax legislation in the } \\
\text { agrarian sector }\end{array}$ & $\begin{array}{l}\text { The possibility of reducing or losing } \\
\text { land areas. Increasing tax and other } \\
\text { pressures; adopting the laws and } \\
\text { regulatory enactments that reduce the } \\
\text { efficiency of the industry functioning }\end{array}$ & $\begin{array}{l}\text { Reduction or termination } \\
\text { of production. } \\
\text { Increase in costs, decrease } \\
\text { in incomes }\end{array}$ \\
\hline
\end{tabular}

Source: the authors' development using [29; 30; 31].

The threats considered in points $9-11$ of Table 1 , are mainly caused by the Ukrainian realities, but may also be topical for other countries.

Ineffective management, erroneous financial strategy or its absence, high level of fixed assets' depreciation (may lead to production suspension, decrease in obtained products and/or deterioration of their quality) and other internal economic threats increase the probability of bankruptcy of a particular agrarian enterprise.

The probability of bankruptcy is also affected by the conditions of doing business in Ukraine, which increase the risk of any business activity, regardless of the field, in particular: high interest rates on bank loans; a high level of corruption; possible illegal takeovers; lower prices for similar imported products. An agrarian enterprise cannot influence these external factors, but it can detect them and develop the strategy to respond to these threats.

In addition to industry, each specific agrarian enterprise has specific risks that expand the typical list.

The risks can push any agrarian enterprise to bankruptcy, but small and mediumsized farms are the most vulnerable, while agro-holdings have the opportunity to insure and hedge their risks.

The typical consequences of the threats' impact on the financial and economic condition of the agrarian enterprise and the probability of bankruptcy, summarized in Table 1, are outlined in Fig. 1.

Monitoring, timely detecting signs of financial crisis and critical insolvency, potential risk factors for bankruptcy and estimating their significance enable to find ways to improve the financial situation and prevent bankruptcy. Estimating the probability of bankruptcy occurrence has certain common features with estimating the probability of any event that may or may not occur. 
Agricultural and Resource Economics: International Scientific E-Journal http://are-journal.com

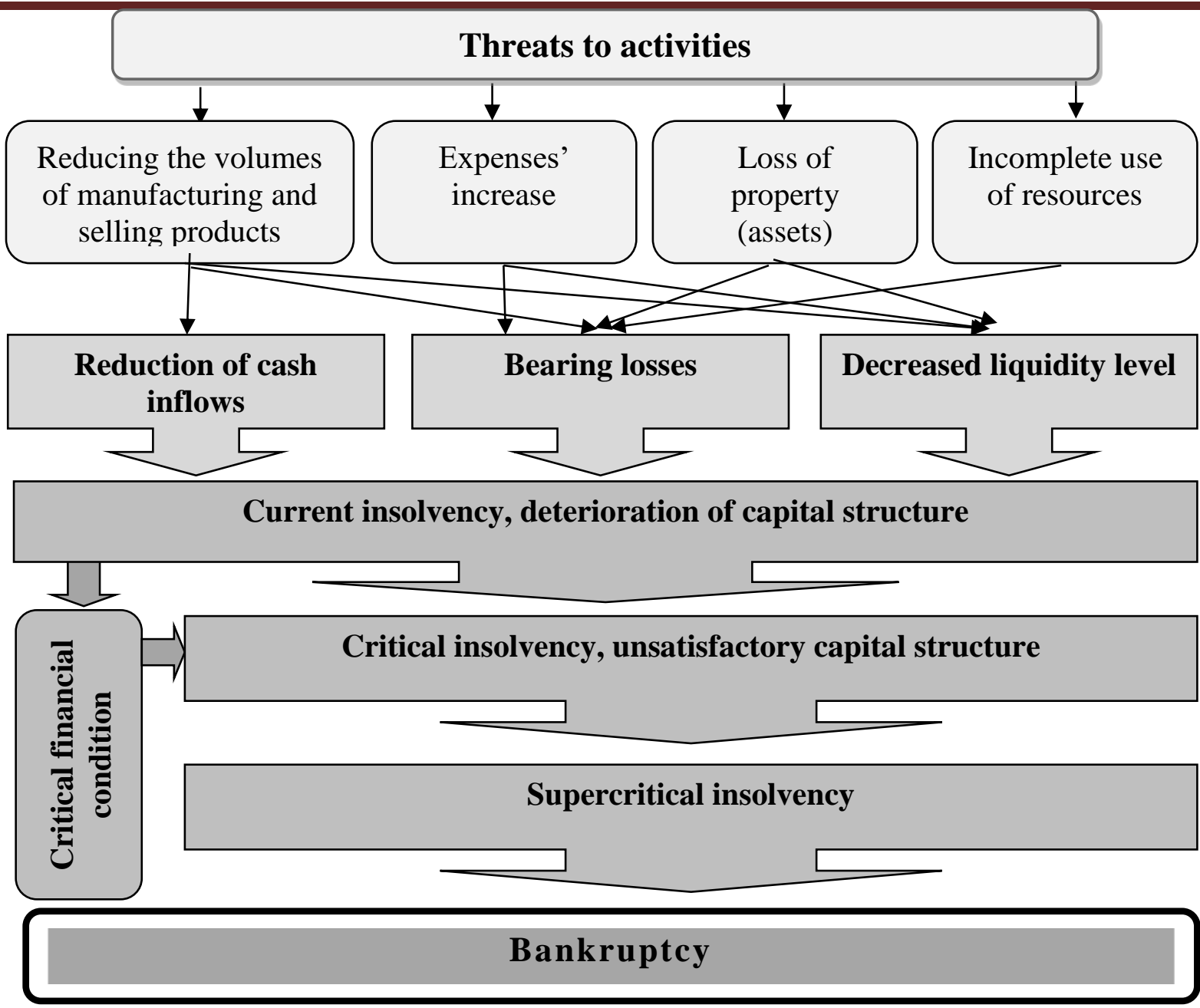

Fig. 1. The impact of activities' threats on the indicators of the probability of bankruptcy

Source: the authors' development.

However, bankruptcy is not an accidental event, but is the final (but not obligatory) stage of a long period of inefficient operation of the agrarian enterprise, accompanied by the disruption of the normal work rhythm and financial problems. Therefore, the signs that precede default can be detected in advance.

Generalization of bankruptcy probability factors is reached by means of multifactor models by calculating integrated index. Discriminant analysis is one of the methods for detecting the manifestations of financial crisis.

The most common multifactor models for bankruptcy prediction are models based on processing financial indicators in order to calculate the integrated index:

- two-factor and five-factor E. I. Altman's model;

- G. L. V. Springate's model;

- discriminant model of R. Lis;

- discriminant model of R. Taffler and G. Tisshaw;

- W. Beaver's test;

- universal discriminant function;

- solvency diagnostics index of J. Conan and M. Holder, and others.

The model of E. I. Altman (1983 version), the founder of the modern analysis of 
bankruptcy probability has the following form:

$$
\mathrm{Z}=0.717 \mathrm{~K}_{1}+0.847 \mathrm{~K}_{2}+3.107 \mathrm{~K}_{3}+0.420 \mathrm{~K}_{4}+0.995 \mathrm{~K}_{5} \text {, }
$$

where $\mathrm{K}_{1} \mathrm{~K}_{2}, \mathrm{~K}_{3}, \mathrm{~K}_{4}$, and $\mathrm{K}_{5}$ are the coefficients calculated by the formulas:

$\mathrm{K}_{1}=$ the average annual value of own operating capital / the average annual value of assets. It characterizes financial stability and solvency;

$\mathrm{K}_{2}=$ the net profit (loss) / the average annual value of assets. It characterizes the return on assets;

$\mathrm{K}_{3}=$ profit (loss) from ordinary activities before taxation / the average annual value of assets. It characterizes the return on assets;

$\mathrm{K}_{4}=$ the average annual cost of owner capital / the average annual value of liabilities. It reflects the capital structure;

$\mathrm{K}_{5}=$ net income (revenue) from selling / the average annual value of assets. It characterizes the turnover of assets.

The obtained results of the index calculation are interpreted as follows:

$\mathrm{Z}<1.23$ - a very high probability of bankruptcy;

$1.23<\mathrm{Z}<2.89$ - a high probability of bankruptcy;

Z> 2.9 - a very low probability of bankruptcy.

According to the similar principle - the calculation of bankruptcy indicators by financial indices, the models listed above and others like them are constructed. Most of them are attempts to improve or adapt Altman's model to particular conditions.

Common advantages of these models for estimating the probability of bankruptcy are the following:

- the use of a small number of coefficients, which ensures the simplicity and speed of calculations;

- the availability of information for the calculation of indicators (financial statements are the source);

- the possibility to compare different objects using integrated estimation;

- mostly certain and clear conclusions;

- the possibility not only to predict bankruptcy, but also to estimate the risk zone, in which the company is located.

For a long time, there were no doubts about the sufficient accuracy of obtained results. However, in 2020, data were published that 98-99\% of firms with Z-criteria below the threshold (1.23) did not file for bankruptcy within two years [17].

Along with the calculation of indices, comparative and qualitative methods to estimate the probability of bankruptcy are also used by diagnosing problems in management, finance, and other aspects of enterprises' activities. This group of methods includes, in particular, the method of J. Argenti, the method of T. Scone, the methods of Ernst \& Whinney company (now called Ernst \& Young), and the method of V. V. Kovaliov

The method of J. Argenti consists in receiving answers to questions in the form of "yes" or "no", which enable to identify drawbacks in the activities of the studied subject, the mistakes made by its managers and the first symptoms of insolvency. Each answer to the question is assessed with a certain number of scores (for example, 15 scores are 
given for a slow and not always adequate response to changing market conditions, 8 scores - for autocracy in the company's top management, etc.); by these scores " $\mathrm{A}$ account" aggregate index is calculated. The value of the calculated index is the basis for estimating the probability of bankruptcy. Thus, the method estimates the state of informal factors that will enable to identify management crisis in the company [3].

The similar approach is the basis of T. Scone's method. The range of aspects covering the issues of his test is wider - they concern business activity, specialization, financial stability, and management. In particular, work in the seasonal industry, the excess of short-term liabilities over circulating assets, combining the positions of the chairman of the board of directors and the executive director by one person, etc. are considered threatening [6].

The methodology of Ernst \& Whinney company consists in estimating qualitative characteristics of the company, among which are both quite traditional (for example, market leadership) and quite unexpected (for example, a fountain in the reception).

However, when applying these methods, it is often possible to obtain opposite conclusions as to bankruptcy probability of the object.

In our opinion, the estimation of bankruptcy probability of agrarian enterprises requires considering industry specifics. Indicators of financial and economic condition are taken into account in the structure of integrated index in the discriminant analysis, but the probability of the agrarian enterprise bankruptcy directly depends on nonfinancial factors of the first order, such as weather conditions, market situation of certain products, size and level of the agrarian enterprise specialization, farm land ownership, and quality of the personnel's work, etc. Thus, these threats can be considered as the factors that affect the likelihood of developing critical insolvency of the agrarian enterprise, so they cannot be ignored when devising bankruptcy probability model.

From our standpoint, the process of estimating the probability of bankruptcy should be carried out by stages (Fig. 2).

At the first stage, the outgoing information is selected for further analysis.

It is expedient to start the prediction of possible bankruptcy with informal analysis - qualitative estimation of sources and causes of risks through expert evaluation. As a result of this stage of the analysis, non-numerical, descriptive characteristics of the impact of each type of risk on the probability of supercritical insolvency are obtained. Because of the lack of standard evaluation criteria, researchers independently formulate the characteristics of the threats' impact on activities. For example, such characteristics can be divided in the following way:

- minimal impact - such a threat almost does not increase the likelihood of bankruptcy risk of the enterprise;

- insignificant impact - such a threat may increase the risk of bankruptcy only under exceptional circumstances or in combination with other threats;

- significant impact that considerably increases the risk of bankruptcy;

- the determining factor, the availability of which will lead to the state of financial crisis and bankruptcy with a high level of probability. 
I. Collection of information

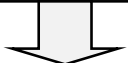

II. Informal (qualitative) analysis -

identification, description, classification of risks, estimation of the degree of their negative impact on activities.

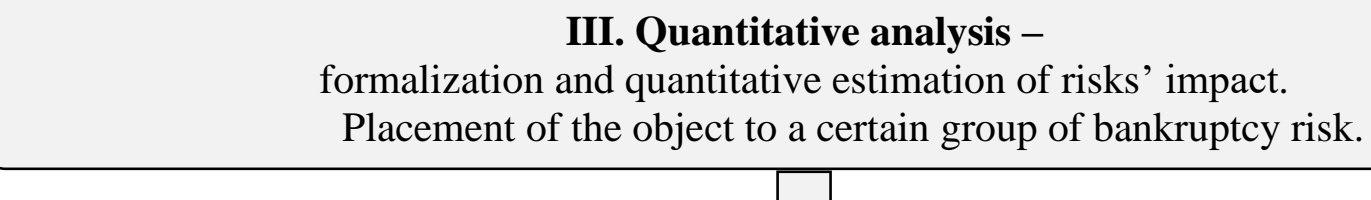

IV. Discriminant analysis -

economic and mathematical modeling, calculating the integrated index of bankruptcy probability using multifactor models.

V. Adjustment of the integrated index on the coefficient, the value of which depends on belonging of the study object to a certain group of bankruptcy risk.

VI. Development and implementation of bankruptcy prevention measures (in case of detecting the threat of its occurrence).

\section{Fig. 2. The main stages of bankruptcy probability analysis}

Source: the authors' development.

We propose to use the characteristics of "insignificant impact", "admissible impact" and "critical impact" in estimating the degree and form of negative impact of the most threatening risks on the activities of an agrarian enterprise (Table 2).

The negative impact of each threat is estimated on a scale of:

- 1 score, if the threat insignificantly increases the probability of bankruptcy, the degree of threat is impossible or difficult to determine;

- 2 scores, if in case of unfavorable event, the probability of bankruptcy will increase significantly, but not critically;

- 3 scores, if there is a risk of significant losses, financial crisis or critical insolvency;

- 5 scores, in cases when even a single negative impact of the factor can lead to bankruptcy. Such consequences are underlined in column 3 of the Table.

The proposed scoring of experts' answers on the impact of the most significant threats can be further specified by the results of large-scale approbation.

As a result of quantitative analysis, qualitative risk characteristics acquire numerical values. The summing up of quantitative estimations of each risk's impact on the activities of a given agrarian enterprise forms the generalized estimation of its tendency to the risk of bankruptcy. This generalized estimation allows the study object 
to be classified as a certain group of bankruptcy risk.

Table 2

\section{Estimation of the impact of the most significant threats on outcomes of agrarian} enterprises

\begin{tabular}{|c|c|c|c|}
\hline \multirow{2}{*}{$\begin{array}{c}\text { Factors that increase the } \\
\text { probability of } \\
\text { bankruptcy }\end{array}$} & \multicolumn{3}{|c|}{ The degree and forms of possible negative impact on the activity } \\
\hline & $\begin{array}{c}\text { Insignificant impact - } \\
1 \text { score }\end{array}$ & $\begin{array}{l}\text { Admissible impact - } \\
2 \text { scores }\end{array}$ & $\begin{array}{l}\text { Critical impact - } \\
3 \text { scores / } 5 \text { scores }\end{array}$ \\
\hline $\begin{array}{l}\text { 1. Adverse weather } \\
\text { conditions }\end{array}$ & $\begin{array}{c}\text { insignificant } \\
\text { expenses, losses can } \\
\text { be compensated by } \\
\text { insurance }\end{array}$ & $\begin{array}{l}\text { reduction of the yields } \\
\text { and fodder base }\end{array}$ & $\begin{array}{l}\text { complete loss of } \\
\text { received products, } \\
\text { bearing losses }\end{array}$ \\
\hline 2. Natural disasters & $\begin{array}{l}\text { insignificant decrease } \\
\text { in yield, admissible } \\
\text { product losses }\end{array}$ & $\begin{array}{l}\text { insufficient receiving } \\
\text { of farm products }\end{array}$ & $\begin{array}{c}\text { complete loss of } \\
\text { received products, } \\
\text { bearing losses }\end{array}$ \\
\hline 3. Narrow specialization & $\begin{array}{c}\text { the company is } \\
\text { diversified }\end{array}$ & $\begin{array}{c}\text { specialization in } 2- \\
3 \text { kinds of products } \\
\text { that give more than } \\
80 \% \text { of income }\end{array}$ & $\begin{array}{c}\text { manufacturing of } \\
\text { only one type of } \\
\text { product }\end{array}$ \\
\hline $\begin{array}{l}\text { 4. Opening of the } \\
\text { market of agricultural } \\
\text { lands }\end{array}$ & $\begin{array}{l}\text { will have a positive } \\
\text { effect, will not affect }\end{array}$ & $\begin{array}{l}\text { unknown, difficult to } \\
\text { determine }\end{array}$ & $\begin{array}{l}\text { significant } \\
\text { reductions of } \\
\text { acreage or } \\
\text { bankruptcy are } \\
\text { possible } \\
\end{array}$ \\
\hline $\begin{array}{l}\text { 5. Production and } \\
\text { technological (non- } \\
\text { following the production } \\
\text { process) in crop growing }\end{array}$ & $\begin{array}{c}\text { insignificant soil } \\
\text { exhaustion, } \\
\text { insignificant yield } \\
\text { decrease }\end{array}$ & $\begin{array}{l}\text { reduction of yields and } \\
\text { quality of products, } \\
\text { essential revenue } \\
\text { reduction }\end{array}$ & $\begin{array}{l}\text { reduction of soil } \\
\text { fertility or its } \\
\text { exhaustion, crop } \\
\text { loss, bearing losses }\end{array}$ \\
\hline $\begin{array}{l}\text { 6. Production and } \\
\text { technological (non- } \\
\text { following the } \\
\text { production process) in } \\
\text { livestock farming }\end{array}$ & $\begin{array}{l}\text { insignificant reducing } \\
\text { of animal } \\
\text { productivity, their } \\
\text { premature culling, } \\
\text { loss of profit }\end{array}$ & $\begin{array}{l}\text { significant livestock } \\
\text { reduction, significant } \\
\text { decrease in the amount } \\
\text { of products, } \\
\text { deterioration of their } \\
\text { quality, revenue } \\
\text { reduction }\end{array}$ & $\begin{array}{l}\text { livestock reduction, } \\
\text { loss of products, } \\
\text { bearing losses }\end{array}$ \\
\hline $\begin{array}{l}\text { 7. Competitive } \\
\text { (reduction of demand } \\
\text { for products, their } \\
\text { competitiveness, etc.) }\end{array}$ & $\begin{array}{l}\text { reduced demand for } \\
\text { the company's } \\
\text { products is hardly } \\
\text { probable }\end{array}$ & $\begin{array}{l}\text { revenue reduction as a } \\
\text { result of decreasing the } \\
\text { volumes of selling } \\
\text { and/or lower prices }\end{array}$ & $\begin{array}{c}\text { losing customers, } \\
\text { bearing losses, being } \\
\text { ousted by } \\
\text { competitors } \\
\end{array}$ \\
\hline $\begin{array}{l}\text { 8. Resource (lack of } \\
\text { basic resources, } \\
\text { depreciation of fixed } \\
\text { assets) }\end{array}$ & $\begin{array}{l}\text { the main technological } \\
\text { processes are provided } \\
\text { with the necessary } \\
\text { resources }\end{array}$ & $\begin{array}{l}\text { there is a risk of } \\
\text { improper performing } \\
\text { technological } \\
\text { operations }\end{array}$ & $\begin{array}{c}\text { cessation of } \\
\text { production, loss of } \\
\text { products, bearing } \\
\text { losses }\end{array}$ \\
\hline 9. Credit & $\begin{array}{c}\text { the company finances } \\
\text { operating costs at its } \\
\text { own means }\end{array}$ & $\begin{array}{c}\text { problems with } \\
\text { financing current } \\
\text { activities because of } \\
\text { inability to obtain } \\
\text { borrowed funds }\end{array}$ & $\begin{array}{l}\text { as a result of non- } \\
\text { receiving the loan or } \\
\text { impossibility of its } \\
\text { repayment there is a } \\
\text { risk of bankruptcy }\end{array}$ \\
\hline $\begin{array}{l}\text { 10. The size of the } \\
\text { enterprise }\end{array}$ & $\begin{array}{l}\text { belongs to agro- } \\
\text { holding }\end{array}$ & $\begin{array}{c}\text { large or medium } \\
\text { enterprise }\end{array}$ & small farming \\
\hline
\end{tabular}


Continuation of table 2

\begin{tabular}{|c|c|c|c|}
\hline $\begin{array}{l}\text { 11. Criminal, corruption } \\
\text { crimes that impede } \\
\text { economic activity }\end{array}$ & $\begin{array}{l}\text { proper internal } \\
\text { security system, no or } \\
\text { unknown cases of } \\
\text { corruption crimes in } \\
\text { the region and } \\
\text { industry }\end{array}$ & $\begin{array}{l}\text { insignificant losses as } \\
\text { a result of stealing } \\
\text { finished products, fuel } \\
\text { and lubricants, etc. } \\
\text { Possible } \\
\text { destabilization of } \\
\text { activities }\end{array}$ & $\begin{array}{c}\text { significant losses as } \\
\text { a result of criminal } \\
\text { activity, the } \\
\text { possibility of } \\
\text { significant losses, } \\
\text { termination of } \\
\text { activities }\end{array}$ \\
\hline $\begin{array}{l}\text { 12. Risks of animal and } \\
\text { plant diseases }\end{array}$ & $\begin{array}{l}\text { owing to the } \\
\text { peculiarities of } \\
\text { production process } \\
\text { and insurance, the } \\
\text { risks are minimal }\end{array}$ & $\begin{array}{l}\text { receiving less than due } \\
\text { products }\end{array}$ & $\begin{array}{l}\text { complete loss of } \\
\text { received products, } \\
\text { bearing losses }\end{array}$ \\
\hline $\begin{array}{l}13 \text {. Risks of self- } \\
\text { reproduction }\end{array}$ & $\begin{array}{c}\text { will not significantly } \\
\text { affect, the necessary } \\
\text { resources are on the } \\
\text { market }\end{array}$ & $\begin{array}{l}\text { additional costs as a } \\
\text { result of external } \\
\text { resources' } \\
\text { replenishment }\end{array}$ & $\begin{array}{l}\text { temporary cessation } \\
\text { of production, loss } \\
\text { of part of products, } \\
\text { additional costs }\end{array}$ \\
\hline $\begin{array}{l}\text { 14. Prohibitions or } \\
\text { restrictions on selling } \\
\text { certain types of products }\end{array}$ & $\begin{array}{c}\text { will not significantly } \\
\text { affect }\end{array}$ & $\begin{array}{l}\text { products will be used } \\
\text { for internal needs }\end{array}$ & $\begin{array}{l}\text { revenue reduction, } \\
\text { bearing losses }\end{array}$ \\
\hline 15. Transport & $\begin{array}{c}\text { insignificant } \\
\text { expenses, damage of } \\
\text { the goods } \\
\text { compensated by the } \\
\text { carrier }\end{array}$ & $\begin{array}{l}\text { increase in costs } \\
\text { because of low } \\
\text { transportability of } \\
\text { certain kinds of } \\
\text { products, irregularities } \\
\text { in transport operations, } \\
\text { etc., loss of part of the } \\
\text { goods, reduced sales }\end{array}$ & $\begin{array}{l}\text { possible loss of } \\
\text { goods during } \\
\text { transportation, loss } \\
\text { of customers, } \\
\text { bearing losses }\end{array}$ \\
\hline $\begin{array}{l}\text { 16. Financial and } \\
\text { investment }\end{array}$ & difficult to determine & $\begin{array}{l}\text { additional costs that } \\
\text { may not paid-back }\end{array}$ & $\begin{array}{l}\text { bearing losses as a } \\
\text { result of incorrect } \\
\text { investment policy }\end{array}$ \\
\hline $\begin{array}{l}\text { 17. Inflation, hryvnia } \\
\text { devaluation }\end{array}$ & difficult to determine & $\begin{array}{l}\text { increased costs, } \\
\text { receiving less incomes } \\
\text { than due }\end{array}$ & bearing losses \\
\hline $\begin{array}{l}\text { 18. Increasing tax } \\
\text { pressure or abolishing } \\
\text { tax benefits in the } \\
\text { agrarian sector }\end{array}$ & $\begin{array}{c}\text { unknown, difficult to } \\
\text { determine }\end{array}$ & $\begin{array}{l}\text { increased costs in tax } \\
\text { settlements }\end{array}$ & $\begin{array}{c}\text { possibility of } \\
\text { significant expenses, } \\
\text { receiving less profit }\end{array}$ \\
\hline $\begin{array}{l}\text { 19. Prohibition or } \\
\text { restriction of } \\
\text { export/import of certain } \\
\text { types of goods }\end{array}$ & insignificant costs & $\begin{array}{l}\text { revenue reduction, } \\
\text { impossibility to obtain } \\
\text { the necessary imported } \\
\text { goods, etc. }\end{array}$ & $\begin{array}{c}\text { receiving losses, the } \\
\text { probability of partial } \\
\text { cessation of } \\
\text { activities }\end{array}$ \\
\hline $\begin{array}{l}\text { 20. Instability of the } \\
\text { political situation }\end{array}$ & $\begin{array}{c}\text { unknown, difficult to } \\
\text { determine }\end{array}$ & $\begin{array}{l}\text { possible loss of several } \\
\text { buyers or suppliers }\end{array}$ & $\begin{array}{c}\text { possibility of } \\
\text { termination of } \\
\text { activity }\end{array}$ \\
\hline
\end{tabular}

Source: the authors' development using [28].

Estimating the impact of threats on the results of activities stipulates the involvement of experts, questioning of competent persons, highly qualified specialists on the researched problem. Experts estimate the risk of bankruptcy occurrence of a 
particular agrarian enterprise using intuition, knowledge and professional experience. To conduct expert examination, it is necessary to create a group of at least three persons from the employees of the enterprise and independent specialists (scientists, highly qualified employees of other agrarian enterprises, etc.).

The subjectivity of experts, which can significantly distort the results, is the disadvantage of expert estimations. Therefore, it is necessary to check experts' estimations for coordination by the concordance coefficient. This can be done using generally available calculator programs that perform calculations and interpret their results online.

We propose to conduct risk analysis by using the system of indices, which are given in Table 2.

According to the results of estimating all components for each expert by summing up these assessments, the total value of the indicator is found (it may be within the range from 20 to 80 ).

Individual estimations of experts are averaged in the final integrated estimation according to the formula of arithmetic mean simple. The final integrated estimation can also range from 20 to 80 scores, and its value is a criterion for scoring - the assignment of the enterprise, the study object, to a certain group of bankruptcy risk.

The corresponding groups shown in Fig. 3 have the following characteristics:

- "the green zone", up to 30 scores - a low or moderate level of bankruptcy risk according to qualitative characteristics of the activity. The coefficient for correcting the integrated index, which will be calculated at the next stage, makes 1.00 , i.e. the integrated index does not require correction;

- "the grey zone", 30-60 scores - the risk to go bankrupt, determined by nonfinancial characteristics of the activity, is probably higher for enterprises in this group than for enterprises in "the green group". Since the identified threats slightly increase the probability of bankruptcy, we propose to use the provisions of mathematical statistics: for practical research the confidence level of probability $\mathrm{p}=0.954$ is sufficient, i.e. the objective measure of the possibility of a particular event makes 95.4\%, and the level of significance in such cases is $\alpha=1-p=1-0.954=0.046$. The last level is used as a correction factor for the result of discriminant analysis: $\mathrm{K}=1+$ $0.046=1.046$;

- "the red zone", over 60 scores is a dangerous level of bankruptcy risk by the determined threats. Thus, the risk of bankruptcy for agrarian enterprises of this group is probably higher than for enterprises of the "green group" and probably higher than for the "grey group", so the level of significance is doubled based on the interval step in scores $(30 \cdot 2=60)$. Accordingly, the correction factor is $K=1+(0.046 \cdot 2)=1.092$.

The values of the correction factors are currently theoretically substantiated, but they can be specified by the results of multiple practical approbations.

An example of conducting the second stage of estimating the probability of bankruptcy is given in Table 3 .

Expert estimations are checked for consistency by the concordance coefficient using math.semestr online calculator. The value of the coefficient $\mathrm{W}=0.7$ indicates 
the average degree of experts' consensus. The calculated Pearson's criterion $\chi^{2}=39.86$ exceeds the tabular value (30.14) at the significance level of $\alpha=0.05$, so the value of the concordance coefficient is a non-random value, and the obtained results can be used at drawing conclusions as to the influence of the factors on the results of given enterprise's activities.

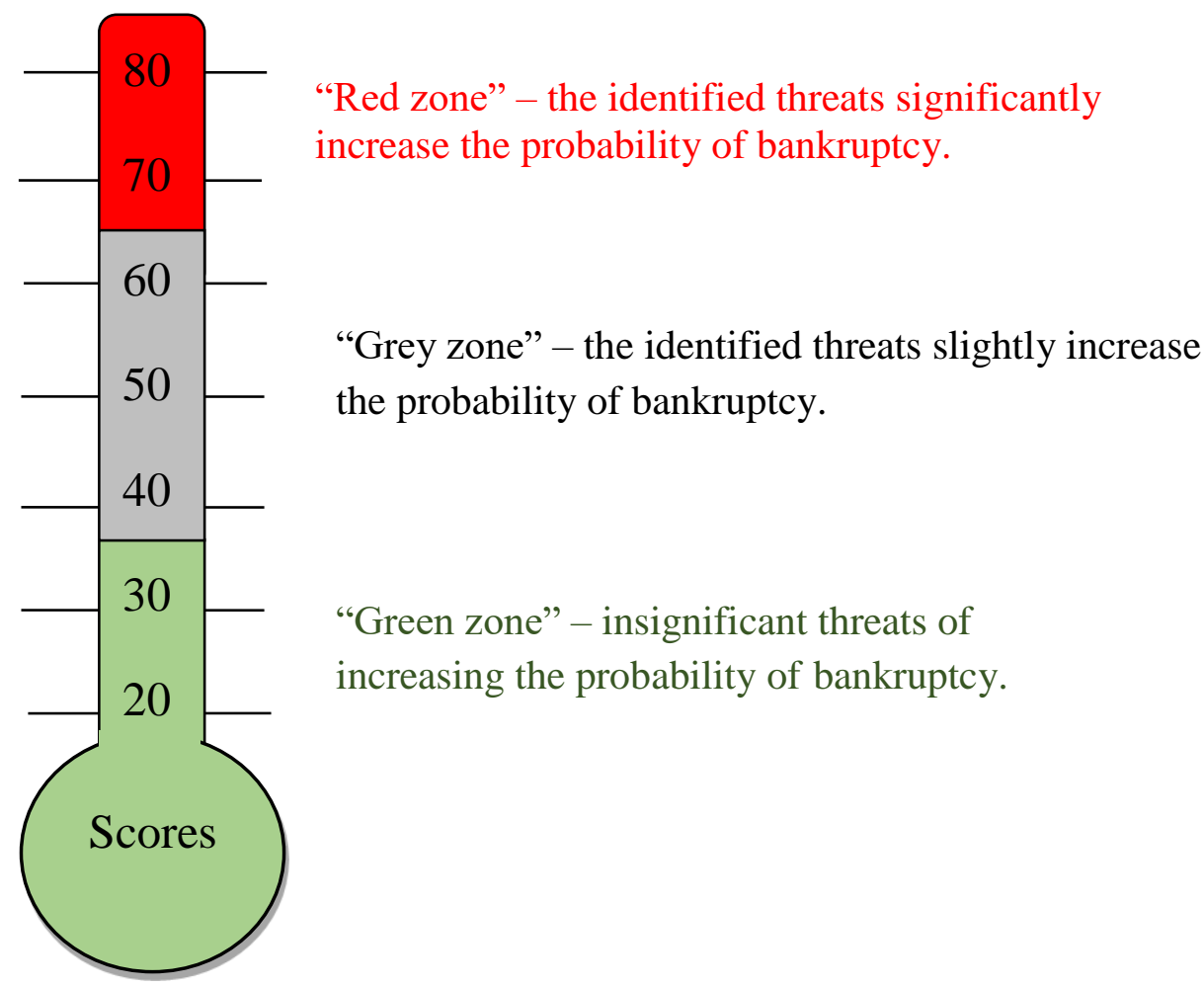

\section{Fig. 3. Integrated estimation of the threats' impact on the probability of bankruptcy of an agrarian enterprise, scores}

Source: the authors' development.

According to the results of questioning three experts on the risks of the enterprise's activities that specializes in grain production and poultry farming, the integrated index of 50 scores was calculated. This means that the study object is in the "grey group", i.e. there is insignificant probability that industry risks will increase bankruptcy probability of the enterprise. The correction factor for the "grey group" makes 1.046, therefore, the integrated index calculated at the next stage of discriminant analysis, should be adjusted to this indicator.

The third stage of diagnostics is bankruptcy prediction by calculating the integrated index using multifactor models. We will demonstrate discriminant analysis on Altman's model of 1983 because of its wide-spreading.

For the above given example (the agrarian enterprise belonging to the group with undetermined risk), the calculated value of the $\mathrm{Z}$-score makes 1.176 . The results of the model's calculation are given in Table 4.

As it has been mentioned above, the "neutral boundary" of the probability of bankruptcy in Altman's model is Z-score $=1.23$, i. e. according to this approach, the company is not threatened with bankruptcy; however, taking into account the 
correction factor, it is already on the verge of the interval.

Table 3

\section{Risk estimation of the impact of the most significant factors on the results of economic activity of the agrarian enterprise " $* * *$ " \\ (specialization - grain production and poultry farming)}

\begin{tabular}{|c|c|c|c|c|}
\hline \multirow{2}{*}{$\begin{array}{l}\text { Factors that cause uncertainty of performance } \\
\text { results }\end{array}$} & \multicolumn{4}{|c|}{ Experts' questioning results (scores) } \\
\hline & $\begin{array}{l}\text { The } 1 \mathrm{st} \\
\text { expert }\end{array}$ & $\begin{array}{l}\text { The } 2 \text { nd } \\
\text { expert }\end{array}$ & $\begin{array}{l}\text { The } 3 \mathrm{~d} \\
\text { expert }\end{array}$ & $\begin{array}{l}\text { Average } \\
\text { rating }\end{array}$ \\
\hline $\begin{array}{l}\text { 1. Adverse weather conditions (winter frosts, } \\
\text { drought, hail, etc.) }\end{array}$ & 5 & 5 & 5 & 5 \\
\hline $\begin{array}{l}\text { 2. Natural disasters (hurricane, downpour, } \\
\text { fire, earthquake, etc.) }\end{array}$ & 5 & 2 & 5 & 4 \\
\hline 3. Narrow specialization & 2 & 3 & 2 & 2 \\
\hline 4. Opening of the market of agricultural lands & 2 & 2 & 5 & 3 \\
\hline $\begin{array}{l}\text { 5. Production and technological in crop } \\
\text { growing }\end{array}$ & 2 & 2 & 2 & 2 \\
\hline $\begin{array}{l}\text { 6. Production and technological in livestock } \\
\text { farming }\end{array}$ & 2 & 5 & 5 & 4 \\
\hline 7. Competitive & 1 & 1 & 2 & 1 \\
\hline 8. Resource & 5 & 2 & 2 & 3 \\
\hline 9. Credit & 1 & 1 & 1 & 1 \\
\hline 10. The size of the enterprise & 2 & 2 & 2 & 2 \\
\hline $\begin{array}{l}\text { 11. Criminal, corruption crimes that } \\
\text { destabilize economic activity }\end{array}$ & 2 & 5 & 2 & 3 \\
\hline $\begin{array}{l}\text { 12. Risks of animal and plant diseases } \\
\text { (epidemics, diseases, pests, etc.) }\end{array}$ & 2 & 2 & 1 & 2 \\
\hline 13. Risks of self-reproduction & 2 & 3 & 3 & 3 \\
\hline $\begin{array}{l}\text { 14. Prohibition or restriction of selling certain } \\
\text { types of products }\end{array}$ & 3 & 3 & 3 & 3 \\
\hline 15. Transportation & 2 & 3 & 3 & 3 \\
\hline 16. Financial and investment & 2 & 2 & 2 & 2 \\
\hline 17. Inflation, hryvnia devaluation & 2 & 2 & 3 & 2 \\
\hline $\begin{array}{l}\text { 18. Increasing tax pressure or cancellation of } \\
\text { tax benefits in the agrarian sector }\end{array}$ & 2 & 2 & 1 & 2 \\
\hline $\begin{array}{l}\text { 19. Prohibitions (restrictions) on } \\
\text { export/import of certain types of goods }\end{array}$ & 2 & 2 & 2 & 2 \\
\hline 20. Instability of the political situation & 1 & 1 & 1 & 1 \\
\hline Together & 47 & 50 & 52 & 50 \\
\hline
\end{tabular}

Source: survey conducted by the authors.

Thus, despite the favorable forecast of discriminant analysis, such an enterprise should form the system of protective mechanisms of anti-crisis management in accordance with the detected factors and the intensity of their impact.

If an agrarian enterprise does not use Altman's model to predict bankruptcy, but another one or several models, the correction of integrated index is conducted similarly. It is used the calculation methodology and evaluation criteria of integrated index (score scales), determined by the authors of a particular model. The correction factors for all the models have the same values (1.0 for the "green zone", 1.046 - for the "grey" and 
1.092 for the "red" ones), and their use can change the value of the calculated integrated index and shift the agrarian enterprise to the group with a higher bankruptcy risk.

Table 4

The results of quantitative estimation of bankruptcy probability of the enterprise " $* * * \% "$

\begin{tabular}{|c|c|c|}
\hline Stage of analysis & $\begin{array}{l}\text { Effective } \\
\text { indicator }\end{array}$ & The essence of the effective indicator \\
\hline $\begin{array}{l}\text { 1. The result of quantitative } \\
\text { analysis of threats to activities }\end{array}$ & 50 & $\begin{array}{l}\text { According to the value of integrated } \\
\text { estimation (Fig. } 3 \text { ), internal and external } \\
\text { threats to activity, with the probability of } \\
95.4 \% \text {, insignificantly increase the risk } \\
\text { of bankruptcy. The correction factor for } \\
\text { the result of the discriminant analysis } \\
\text { makes } \mathrm{K}=1.046\end{array}$ \\
\hline $\begin{array}{l}\text { 2. The result of the discriminant } \\
\text { analysis of the probability of } \\
\text { bankruptcy using Altman's model } \\
\text { (formula 1) }\end{array}$ & 1.176 & $\begin{array}{c}\text { The calculated indicator is lower than } \mathrm{Z} \text { - } \\
\text { score }=1.23 \text {, i.e. in the coming years the } \\
\text { company is not threatened with } \\
\text { bankruptcy }\end{array}$ \\
\hline $\begin{array}{l}\text { 3. Specification of the discriminant } \\
\text { analysis' result taking into account } \\
\text { the correction factor }\end{array}$ & $\begin{array}{c}1.176 \cdot 1.046= \\
1.230\end{array}$ & $\begin{array}{c}\text { The company is at the lower boundary of } \\
\text { the interval }(1.23-2.89) \text {, which } \\
\text { determines quite a high probability of } \\
\text { bankruptcy }\end{array}$ \\
\hline
\end{tabular}

Source: questioning conducted by the authors.

At the last stage, agrarian enterprises, in which the threat of bankruptcy has been detected, must quickly develop the complex of measures to prevent it. Bankruptcy prevention plan for each company must include measures to prevent exactly those threats that were identified at the previous stages of the analysis. According to the results of expert assessment (Table 3 ) for the enterprise, the study object, critically affecting threats were identified and graded according to the degree of their impact on the activities (Table 5).

As we can see, the most serious threats to the given agrarian enterprise are external risk factors - adverse weather conditions and natural disasters. Therefore, in order to reduce critically dangerous impact of these factors on economic activities, the enterprise needs to minimize losses by insuring risks. The company has to respond to internal risks using the strategy of early detection and prevention of possible threats.

General recommendations for agrarian enterprises with a high probability of bankruptcy are the following:

- the formation of an effective strategy for making managerial decisions to attract, allocate and use financial resources;

- the creation of reserve funds for stocks of the most important resources and capital to cover possible costs;

- increasing the competitiveness of products;

- the diversification of non-competitiveness risks of the enterprise;

- increasing the turnover of operating assets;

- the optimization of the ratio of own and borrowed funds, etc. 
The revealed treats to economic activities of the agrarian enterprise "****" (specialization - grain production and poultry farming)

\begin{tabular}{|l|c|c|}
\hline \multicolumn{1}{|c|}{$\begin{array}{c}\text { Factors that cause uncertainty of } \\
\text { performance results }\end{array}$} & $\begin{array}{c}\text { Mean score according to } \\
\text { the questioning of } \\
\text { experts }\end{array}$ & Source of threat \\
\hline $\begin{array}{l}\text { 1. Adverse weather conditions } \\
\text { (winter frosts, drought, hail, etc.) }\end{array}$ & 5 & External (exogenous) factor \\
\hline $\begin{array}{l}\text { 2. Natural disasters (hurricane, } \\
\text { downpour, fire, earthquake, etc.) }\end{array}$ & 4 & Internal (endogenous) factor \\
\hline $\begin{array}{l}\text { 3. Production and technological in } \\
\text { livestock farming }\end{array}$ & 4 & External (exogenous) factor \\
\hline $\begin{array}{l}\text { 4. Opening of the market of } \\
\text { agricultural lands }\end{array}$ & 3 & It can be both external and \\
\hline $\begin{array}{l}\text { 5. Prohibition or restriction of selling } \\
\text { certain types of products }\end{array}$ & 3 & It can be both external and \\
\hline $\begin{array}{l}\text { 6. Criminal, corruption crimes that } \\
\text { destabilize economic activity }\end{array}$ & 3 & Internal (endogenous) factor \\
\hline 7. Resource & 3 & Internal (endogenous) factor \\
\hline 8. Risks of self-reproduction & 3 & Internal (endogenous) factor \\
\hline 9. Transport & 3 & \\
\hline
\end{tabular}

Source: questioning conducted by the authors.

Thus, the main concept of our proposals to improve the existing methodology for estimating the probability of bankruptcy is the combination of financial indices and quantitative estimation of risks that have the greatest impact on the activities of agrarian enterprises. Owing to the complex approach, our proposed improvements will increase the accuracy of estimating the prospects for the development of the agrarian sector and the probability of its bankruptcy.

Conclusions. The specifics of the Ukrainian enterprises' work in the agrarian sector are a complex of risks and threats that require timely response to prevent bankruptcy. Specifying the main risks to agricultural activities in Ukraine enabled to classify and schematize their impact on the probability of agrarian enterprises' bankruptcy.

The proposed definition of the term "bankruptcy" combines legal and economic aspects, it emphasizes that bankruptcy is recognized only by the court and the given definition also specifies that the bankrupt experiences not just insolvency, but supercritical insolvency.

At present, the most common methodological approaches to estimating the probability of bankruptcy occurrence are discriminant analysis - the creation of multifactor models (universal, not adapted to enterprises of different industries) and the methods of qualitative estimation of the probability of bankruptcy. We propose to combine these two approaches and take into account industry risks as factors that increase the probability of bankruptcy.

We propose to analyze the probability of bankruptcy in the following sequence:

1. Detecting risks and estimating the degree of negative impact on activities. We 


\section{Agricultural and Resource Economics: International Scientific E-Journal http://are-journal.com}

have systematized the factors that may increase the risk of bankruptcy of agrarian enterprises.

2. Expert quantitative estimating in scores for the degree of impact of separate threats on the probability of bankruptcy.

According to the results of estimating all the components by their summing up, the total value of the index is found, according to which the study object is attributed to one of three groups of bankruptcy risk: with a low or moderate level (the correction factor is 1.00), the admissible level (the correction factor is 1.046), and with a critically dangerous level of risk (the correction factor is 1.092). In our opinion, the introduction of the correction factor for agrarian enterprises is necessary because of the greater unpredictability of agrarian activities, which increases the probability of unexpected bankruptcy.

3. The calculation of probability of bankruptcy integrated index by using multifactor models.

4. The adjustment of the integrated index to the correction factor in accordance with a definite group of bankruptcy risk.

5. Making managerial decisions to prevent bankruptcy.

Thus, using the method of expert estimations, the scoring model was created; also the scale was developed and combined with the discriminant model. Owing to this, the score scale was evaluated and the results of the study were derived to the indicator interval to estimate the onset of bankruptcy.

Our further research will be aimed at repeated testing of the proposed methodological approach on the materials of various agrarian enterprises and observing them for at least 2-3 years to verify bankruptcy predictions concerning the entities that, according to our estimations, are classified as critically dangerous.

\section{References}

1. State Statistics Service of Ukraine (2021), Number of business entities by type of economic activity in 2010-2019, available at: http://www.ukrstat.gov.ua.

2. Altman, E. I. (1984), A further empirical investigation of the bankruptcy cost question. Journal of Finance, vol. 39, no. 4, pp. 1067-1089. https://doi.org/10.2307/2327613.

3. Argenti, J. (1976), Corporate collapse: the causes and symptoms. Holsted Press, McGraw-Hill, London.

4. Beaver, W. (1966), Financial ratios as predictors of failure. Journal of Accounting Research, vol. 4, pp. 71-111. https://doi.org/10.2307/2490171.

5. Knight, F. H. (1921), Risk, uncertainty, and profit. Hart, Schaffner, and Marx Prize Essays, no. 31. Houghton Mifflin, Boston and New York, USA.

6. Skoun, T. (1997), Upravlencheskiy uchet [Managerial Accounting], Audit; YuNITI, Moscow, Russia.

7. Springate, G. L. V. (1978), Predicting the possibility of failure in a Canadian firm. Unpublished M.B.A. Research Project, Simon Fraser University, Canada.

8. Tetens, J. N. (1786), Einleitung zur Berechnung der Leibrenten und Anwartschaften, Leipzig, Germany. 
9. Alaminos, D., del Castillo, A., and Fernández, M. Á. (2018), Correction: A Global Model for Bankruptcy Prediction. PLoS ONE, vol. 13(11), e0208476. https://doi.org/10.1371/journal.pone.0208476.

10. Jaki, A. and Cwiek, W. (2021), Bankruptcy prediction models based on value measures. Journal of Risk and Financial Management, vol. 14(1), 6. https://doi.org/10.3390/jrfm14010006.

11. Horváthová, J. and Mokrišová, M. (2018), Risk of bankruptcy, its determinants and models. Risks, vol. 6(4), 117. https://doi.org/10.3390/risks6040117.

12. Prusak, B. (2018), Review of research into enterprise bankruptcy prediction in selected central and eastern European countries. International Journal of Financial Studies, vol. 6(3), 60. https://doi.org/10.3390/ijfs6030060.

13. Shumway, T. (2001), Forecasting bankruptcy more accurately: a simple hazard model. The Journal of Business, vol. 74, no. 1, pp. 101-124. https://doi.org/10.1086/209665.

14. Bărbuță-Mișu, N. and Madaleno, M. (2020), Assessment of bankruptcy risk of large companies: European countries evolution analysis. Journal of Risk and Financial Management, vol. 13(3), 58. https://doi.org/10.3390/jrfm13030058.

15. Hosaka, T. (2019), Bankruptcy prediction using imaged financial ratios and convolutional neural networks. Expert systems with applications, vol. 117, pp. 287299. https://doi.org/10.1016/j.eswa.2018.09.039.

16. Papana, A. and Spyridou, A. (2020), Bankruptcy prediction: the case of the greek market. Forecasting, vol. 2(4), pp. 505-525. https://doi.org/10.3390/forecast2040027.

17. Heaton, J. B. (2020), The Altman Z score does not predict bankruptcy. AIRA Journal, vol. 33(3), pp. 33-34. https://doi.org/10.2139/ssrn.3570149.

18. Lukason, O. and Andresson, A. (2019), Tax arrears versus financial ratios in bankruptcy prediction. Journal of Risk and Financial Management, vol. 12(4),187. https://doi.org/10.3390/jrfm12040187.

19. Aleksanyan, L. and Huiban, J.-P. (2016), Economic and financial determinants of firm bankruptcy: evidence from the French food industry. Review of Agricultural, Food and Environmental Studies, vol.97, pp. 89-108. https://doi.org/10.1007/s41130-016-0020-7.

20. Dinterman, R., Katchova, A. L. and Harris, M. J. (2018), Financial stress ad farm bankruptcies in U.S. agriculture. Agricultural Finance Review, vol. 78, no. 4, pp. 441-456. https://doi.org/10.1108/AFR-05-2017-0030.

21. Valaskova, K., Durana, P., Adamko, P. and Jaros, J. (2020), Financial compass for Slovak enterprises: modeling economic stability of agricultural entities. Journal of Risk and Financial Management, vol. 13(5), 92. https://doi.org/10.3390/jrfm13050092.

22. Savickaja, G. V. (2017), Jekonomicheskij analiz [Economic analysis], 14nd ed, Infra-M, Moskva, Russia.

23. Tereshchenko, O. O. (2004), Antikrizove finansove upravlinnya na pidpriemstvi [Crisis financial management at the enterprise], KNEU, Kyiv, Ukraine. 
24. Melikhova, T. (2019), Bankruptcy probability estimation to improve the financial condition of the enterprise. Ahrosvit, vol. 10, pp. 11-18.

25. Rudyka, V. I., Velykyi, Yu. M. and Zema, O. D. (2018), The economic essence of the concept of «bankruptcy», causes, and consequences for the enterprise. Infrastruktura rynku, vol. 18, pp. 127-132.

26. Chupis, A. V.ed. (1999), Fynansovoe polozhenye predpryyatyya: otsenka, analyz, planyrovanye [The financial position of the enterprise: evaluation, analysis, planning], Unyversytetskaya knyha, Sumy, Ukraine.

27. Tranchenko, A. M. (2013), Bankruptcy prediction in the context of the competitiveness of agriculture. Ekonomika ta derzhava, vol. 12, pp. 44-46.

28. Yehorova, O., Dorohan-Pysarenko, L., Chip, L. and Tyutyunnik, M. (2019), Assessment of entrepreneurial risks in agriculture. Technology audit and production reserves, vol.1/4(45), pp. 4-10. https://doi.org/10.15587/2312-8372.2018.146943.

29. Vishnevskaya, O. O. and Voytseshina, N. I. (2017), The causes and features of management of business risk in agribusiness. Visnyk Khersonskoho derzhavnoho universytetu. Ser.: Ekonomichni nauky, vol. 23(I), pp. 142-145.

30. Zhmurko, I. (2017), Risks in agricultural sector and the need of their insurance. Economic discourse, vol. 1, pp. 42-49.

31. Zakharchenko, O. (2016), Risk management at enterprises of livestock. Formuvannia rynkovykh vidnosyn v Ukraini, vol. 3, pp. 61-66.

\section{Citation:}

\section{Стиль - ДСТУ:}

Dorohan-Pysarenko L., Rębilas R., Yehorova O., Yasnolob I., Kononenko Z. Methodological peculiarities of probability estimation of bankruptcy of agrarian enterprises in Ukraine. Agricultural and Resource Economics. 2021. Vol. 7. No. 2. Pp. 20-39. https://doi.org/10.51599/are.2021.07.02.02.

Style-APA:

Dorohan-Pysarenko, L., $\quad$ Rębilas, R., $\quad$ Yehorova, O., $\quad$ Yasnolob, I. and Kononenko, Z. (2021), Methodological peculiarities of probability estimation of bankruptcy of agrarian enterprises in Ukraine. Agricultural and Resource Economics, vol. 7, no. 2, pp. 20-39. https://doi.org/10.51599/are.2021.07.02.02. 